\title{
Epiphytic Populations of Xanthomonas albilineans and Subsequent Sugarcane Stalk Infection Are Linked to Rainfall in Guadeloupe
}

\author{
P. Champoiseau, Cirad, UPR Multiplication Végétative, Petit-Bourg, Guadeloupe, F-97170 France; P. Rott, Cirad, \\ UMR Cirad-Inra-Montpellier SupAgro Biologie et Génétique des Interactions Plante-Parasite (BGPI), TA A-54/K, \\ Campus International de Baillarguet, Montpellier Cedex 5, F-34398 France; and J.-H. Daugrois, Cirad, UPR Multi- \\ plication Végétative, Petit-Bourg, Guadeloupe, F-97170 France
}

\begin{abstract}
Champoiseau, P., Rott, P., and Daugrois, J.-H. 2009. Epiphytic populations of Xanthomonas albilineans and subsequent sugarcane stalk infection are linked to rainfall in Guadeloupe. Plant Dis. 93:339-346.

Three separate field trials were established in Guadeloupe under different agronomic and rainfall conditions to study phyllosphere contamination and infection of sugarcane plants by Xanthomonas albilineans, the causal agent of sugarcane leaf scald. Disease-free and leaf scald susceptible cv. B69566 was planted and monitored during three 1-year crop cycles. Presence of leaf scald contaminated sugarcane fields in the proximity of the disease-free trials appeared critical in early contamination of the sugarcane phyllosphere. Later on, particular meteorological events, such as tropical storms, were also important in aerial spread of the pathogen. A positive correlation was found between epiphytic populations of $X$. albilineans and severity of leaf necrotic symptoms, but occurrence of leaf symptoms was not always related to subsequent stalk infection. However, when the data of the three crop seasons were considered together, a high correlation was found between rainfall and maximum epiphytic populations of $X$. albilineans, and between rainfall and subsequent stalk infections. Consequently, rainfall is a key factor to be considered in evaluation of risks of leaf scald epidemics, and protocols for propagation of healthy sugarcane material and screening methods for leaf scald resistance may have to be revised in humid tropical locations.
\end{abstract}

Xanthomonas albilineans is a bacterial vascular pathogen that causes leaf scald of sugarcane (Saccharum interspecific hybrids). This disease occurs in numerous sugarcane growing locations worldwide and can cause severe yield losses in susceptible cultivars (29).

Leaf symptoms of systemically infected sugarcane vary from a single, white, narrow, sharply defined stripe to complete necrosis and wilting of infected leaves. Another common symptom in mature cane is the abnormal development of side shoots on stalks (29). The disease is also characterized by a latency phase during which sugarcane can be infected by the pathogen for several months without showing symptoms. Therefore, the pathogen can be spread by inadvertent contamination of knives and harvesters, and by planting of infected cuttings from symptomless plants. Movement of infected cuttings largely contributed to the propagation of the pathogen worldwide (29). For years, management of leaf scald was based on phytosanitary measures to control exchange of

Corresponding author: J.-H. Daugrois

E-mail: jean-heinrich.daugrois@ cirad.fr

Accepted for publication 8 November 2008.

doi:10.1094/PDIS-93-4-0339

(C) 2009 The American Phytopathological Society sugarcane material and propagation of the disease. These measures included the use of quarantine facilities, the planting of healthy seed-cane from plants grown from disease-free tissue cultured plantlets (14) or from hot-water treated stalks (12), and the use of resistant cultivars (39). Improvement of diagnostic techniques also contributed to better detection of the disease (9).

During the last two decades, outbreaks of the disease occurred in several geographical locations throughout the world $(1,5,7,11,18,21,26,30)$. In Florida, Guadeloupe, and Mauritius, new outbreaks were associated with aerial transmission of the pathogen $(1,6,8,22)$. Most, if not all, of these outbreaks were attributed to new or specific genetic variants of the pathogen $(4,10)$. In Florida, it was suggested that leaf scald outbreaks were linked to variants of the pathogen that survive better epiphytically or have greater propensity toward aerial transmission (10), but this hypothesis has not been proven so far.

Although $X$. albilineans was initially thought to be spread by contaminated harvesting tools and infected planting material, aerial transmission of the pathogen appears also to play a key role in the epidemiology of sugarcane leaf scald. Indeed, $X$. albilineans was found in the rhizosphere of infected roots (22), in guttation droplets (1), on the leaf surface of symptomatic and symptomless plants, and in aerosols in a diseased field (22), suggesting the existence of natural inoculum sources for aerial transmission of the pathogen. In Mauritius, the leaf scald pathogen has spread from sugarcane to maize grown between sugarcane rows (1). Additionally, several weeds growing in or near sugarcane fields may serve as reservoirs of inoculum for X. albilineans (2). In Guadeloupe, leaf symptoms attributed to aerial transmission of $X$. albilineans were first observed in sugarcane fields in 1993. Later on, the pathogen was isolated from sugarcane stalks of plants exhibiting necrotic leaf symptoms attributed to aerial contamination in a nursery plot that was set up with disease-free, tissue-cultured plants of cv. B69566 (J.-H. Daugrois and L. Costet, unpublished data). These results were the first evidence of sugarcane infection after aerial transmission in Guadeloupe, and they confirmed similar observations made in Mauritius in the 1990s (33). Recently, it was also shown that colonization of the sugarcane phyllosphere by $X$. albilineans, and subsequent infection of sugarcane stalks, can vary according to the strain of the pathogen and the sugarcane cultivar (8). Additionally, other factors, such as meteorological events, may play a crucial role in field contamination by favoring long-distance movement of the pathogen. In Louisiana, leaf scald outbreaks were suspected to be favored by rainstorms and cyclones (20). In Guadeloupe, bacterial populations of $X$. albilineans were first detected on the leaf surface of healthy sugarcane shortly after a tropical storm (8).

The objective of this study was to better characterize the factors involved in aerial contamination, epiphytic survival, and subsequent infection of sugarcane stalks by $X$. albilineans. Bacterial population density, symptom severity, and percent stalk infection were characterized in relation to genetic and serological characteristics of the pathogen, and to climatic conditions with special emphasis on rainfall.

\section{MATERIALS AND METHODS}

Plant material and experimental design. Three separate field trials (A, B, and C) were established in Guadeloupe under different environmental (agronomic and climatic) conditions, and divided into ex- 
perimental quadrates (Table 1). The experiment was conducted with disease-free tissue-cultured plants of sugarcane $\mathrm{cv}$. B69566, which is susceptible to leaf scald (31). Plants were propagated in vitro and transferred to the greenhouse as described by Feldmann et al. (14). Six-week-old greenhouse plants were transferred to the field, where each plant was drip irrigated with 8 liters of water per week, during the first 3 to 4 weeks of the trial, to ensure initial plant growth. Trials were conducted for 3 years with crop seasons of 12 months each: plant cane crop (PC), 1st ratoon crop (R1), and 2nd ratoon crop (R2) for crop seasons 1,2 , and 3 , respectively.

Harvesting method. At the end of each crop season, sugarcane in each field trial was manually harvested using cutting knives, and stalks were cut near ground level (13).

Climatic data. Daily rainfall, number of rainy days, number of days with rainfall $>6$ $\mathrm{mm}$, and total rainfall during the wet season (from the beginning of June to the end of December) were monitored for each of the three field trials and for each crop season, from 1999 to 2002 . The threshold of 6 $\mathrm{mm}$ was chosen based on the amount of daily water needed for sugarcane growth (13).

Populations of the pathogen on leaf surface. In the three field trials, first detection of $X$. albilineans and progress of epiphytic populations of the pathogen were determined by sampling water droplets at the surface of sugarcane leaves early in the morning (from 6 to 7 A.M.). At the beginning of the experiment, before first detection of the pathogen in field trials, water droplets were sampled every 2 weeks in every two quadrates. In selected quadrates, one droplet of water was sampled per plant (32 droplets sampled per quadrate). After first detection of the pathogen in a field trial, water droplets were sampled in all quadrates and on every two plants (16 droplets sampled per quadrate), until water droplets were no longer collectable on the leaf surface at the beginning of the dry season. Samples were collected every 2 to 3 weeks in each field trial. Water droplets were sampled with a $200-\mu l$ micropipette, and new sterilized micropipette tips were used for each sampled quadrate. Water droplets sampled in each quadrate were pooled in a 2-ml sterilized microtube and then transferred to the laboratory for analysis.

Twenty microliters of each pooled sample was diluted 100-fold in sterile distilled water. $X$. albilineans populations were determined by plating the undiluted samples and the 100-fold dilutions on selective agar medium (XAS) (9) with the Spiral system, as recommended by the manufacturer (Interscience, Saint-Non-La-Bretèche, France). Bacterial counts were determined after 5 days of incubation of agar plates at $28^{\circ} \mathrm{C}$. Epiphytic population densities of the pathogen $\left(\mathrm{Pop}_{\mathrm{epi}}\right)$ were expressed in $\mathrm{CFU} / \mathrm{ml}$. Visual identification of $X$. albilineans colonies was verified randomly by serology (30).

Symptom assessment on leaves. During PC crop, necrotic leaf lesions attributed to aerial spread of $X$. albilineans were recorded in trials $\mathrm{A}$ and $\mathrm{C}$ to assess symptom severity. Because of the late appearance, symptoms were not recorded in field trial B. When leaf scald symptoms were first observed in a trial, 20 stalks were randomly selected among plants that showed leaf symptoms. These stalks were then used to record symptoms on leaves 3 , $6,9,13,18$, and 23 weeks after first detection of symptoms in trial $\mathrm{A}$, and $1,5,8$, and 13 weeks in trial $\mathrm{C}$, respectively. Stalks were rated individually based on symptoms recorded on all leaves of the stalk, using a symptom severity scale ranging from 0 to 5 , where $0=$ no symptom, 1 $=$ one small necrotic lesion $(<10 \mathrm{~cm}$ in length) on one leaf, $2=$ one small necrotic lesion on more than one leaf, $3=$ more than one small necrotic lesion on more than one leaf, $4=$ more than one small necrotic lesion on more than one leaf and one large necrotic lesion $(>10 \mathrm{~cm}$ in length) on one leaf, and $5=$ large necrotic lesions on more than one leaf. Symptom severity on leaves was expressed as $S_{S}=(1$ $\times N_{1}+2 \times N_{2}+3 \times N_{3}+4 \times N_{4}+5 \times$ $\left.N_{5}\right) / N_{T}$, where $N_{i}=$ number of stalks with score $i$ and $N_{T}=$ total number of stalks.

At the end of PC crop, the stalks sampled for systemic colonization (see below) were rated individually for presence of leaf symptoms attributed to aerial spread of $X$. albilineans in trials $\mathrm{A}$ and $\mathrm{B}$. Because of occurrence of numerous necrotic leaf lesions attributed to local drought, leaf scald symptoms could not be recorded on stalks in trial C. Symptom occurrence on leaves was expressed as the percentage of stalks with symptoms on leaves.

Systemic colonization of sugarcane stalks. At the end of each crop season, sugarcane stalks were randomly sampled in every row in each field trial to a total of 200 to 304 stalks per trial. Systemic infection of each stalk was assessed by isolating the pathogen from two different stalk locations, $\mathrm{L}_{\mathrm{B}}$ and $\mathrm{L}_{\mathrm{T}}$, where $\mathrm{L}_{\mathrm{B}}$ corresponded to the 3 to 4 internodes at the base of the sugarcane stalk and $\mathrm{L}_{\mathrm{T}}$ corresponded to the 3 to 4 last internodes near the top (below the meristem) of the stalk. Imprints of cut sections at each stalk location were performed by the stalk blot inoculation technique with XAS selective medium, as previously described (4). Growth of $X$. albilineans was recorded after 5 days of incubation of agar plates at $28^{\circ} \mathrm{C}$, and visual identification of the bacterial colonies was verified randomly by serology (30). Systemic stalk colonization of sugarcane plants was expressed as the percentage of stalks infected by $X$. albilineans at stalk locations $\mathrm{L}_{\mathrm{B}}$ and $\mathrm{L}_{\mathrm{T}}$.

Characterization of bacterial strains. Fifty-four strains were randomly sampled in all field trials and crop seasons. Each strain was subcultured from a single colony on XAS selective medium, and serological characteristics of strains were determined as described by Rott et al. (30). Genetic diversity (based on variability of a $55-\mathrm{kb}$ genomic region involved in biosynthesis of the toxin albicidin) and variability in pathogenicity (based on disease severity and intensity of stalk colonization) of the 54 strains isolated in this study were determined in a previous study that included 137 strains of $X$. albilineans from worldwide locations (4).

Statistical analyses. Spatial analysis of bacterial dispersion in each field trial was performed with the sdep module of $\mathrm{R}$ software (version 2.0.1; Department of Statistics and Mathematics, Wirtschaftsuniversität, Vienna, Austria). Correlation between infected quadrates was analyzed using the join-count statistic and the Moran test (25). All regression and corre-

Table 1. Characteristics of the three field trials used to study sugarcane stalk infection by Xanthomonas albilineans following aerial spread of this pathogen in Guadeloupe ${ }^{\mathrm{a}}$

\begin{tabular}{|c|c|c|c|c|c|c|c|}
\hline Trial & Field name & $\begin{array}{l}\text { Location in } \\
\text { Guadeloupe }\end{array}$ & Planting date & Field area & $\begin{array}{l}\text { Number of } \\
\text { quadrates }^{b}\end{array}$ & $\begin{array}{c}\text { Climatic } \\
\text { conditions }^{c}\end{array}$ & $\begin{array}{c}\text { Agronomic } \\
\text { environment }\end{array}$ \\
\hline A & Saint-Jean & North BT & 11 May 1999 & $1,100 \mathrm{~m}^{2}$ & 25 & $\mathrm{H}$ & $\mathrm{ScP}$ \\
\hline B & Duclos & North BT & 26 May 1999 & $1,600 \mathrm{~m}^{2}$ & 35 & $\mathrm{HH}$ & $\mathrm{ScA}$ \\
\hline $\mathrm{C}$ & Godet & North GT & 19 May 1999 & $1,400 \mathrm{~m}^{2}$ & 35 & MH & $\mathrm{ScP}$ \\
\hline
\end{tabular}

a Six-week-old greenhouse plants of sugarcane cv. B69566 were linearly transplanted to the fields; field rows were separated by $1.5 \mathrm{~m}$ and plants were separated by $0.5 \mathrm{~m}$ on each row. Abbreviations: $\mathrm{BT}=$ Basse-Terre, GT = Grande-Terre, and ScP and ScA = sugarcane fields contaminated by X. albilineans present $(\mathrm{ScP})$ and absent $(\mathrm{ScA})$ in the proximity (within a distance of about $1 \mathrm{~km})$.

${ }^{\mathrm{b}}$ Each trial was divided into quadrates of 6.8 by $4.0 \mathrm{~m}$ that included 32 plants (4 rows of 8 plants) each.

${ }^{c}$ Based on the average of annually cumulated daily rainfall over the 40 years preceding the experiment $\left(\mathrm{MR}_{40}\right)$. $\mathrm{Abbreviations}$ : $\mathrm{HH}=\mathrm{highly}$ humid $\left(\mathrm{MR}_{40}=\right.$ $2,807 \mathrm{~mm}), \mathrm{H}=$ humid $\left(\mathrm{MR}_{40}=2,074 \mathrm{~mm}\right)$, and $\mathrm{MH}=$ moderately humid $\left(\mathrm{MR}_{40}=1,421 \mathrm{~mm}\right)$. 
lation analyses were performed with SigmaPlot (version 7.0; SPSS Science Inc., Chicago, IL).

\section{RESULTS}

Daily rainfall and meteorological events. Annual rainfall (cumulated daily rainfall) varied greatly among crop seasons $\mathrm{PC}, \mathrm{R} 1$, and R2, with delta values (maximum value minus minimum value) of 829 , 878 , and 808 in trials $\mathrm{A}, \mathrm{B}$, and $\mathrm{C}$, respectively. Variation of annual rainfall values in the three field trials for the three crop seasons was relatively similar, with minimum rainfall values observed in $\mathrm{R} 1 \mathrm{crop}$ in each trial (Fig. 1). Similar variations were observed with the monthly mean rainfall values obtained for each crop season and each trial (Table 2). However, important variations were observed among months as indicated by the minimum, maximum, and mean square values. During PC crop, particular meteorological events occurred that were followed by heavy rains and winds in different geographical locations in Guadeloupe: first tropical depression on $22 \mathrm{Au}-$ gust 1999 in North Grande-Terre; hurri- cane Jose on 21 October 1999 in North Basse-Terre; second tropical depression on 10 November 1999 in North Basse-Terre; and main hurricane Lenny on 18 and 19 November 1999 in North Basse-Terre and North Grande-Terre.

First detection and spread of epiphytic populations of $X$. albilineans in plant cane crop. Bacterial populations of $X$. albilineans were first detected in water droplets on the leaf surface 9,25 , and 17 weeks after transferring plants to the field in trials $\mathrm{A}, \mathrm{B}$, and $\mathrm{C}$, respectively. After first detection of the pathogen, the progress pattern of epiphytic bacterial population $\left(\right.$ Pop $\left._{\text {epi }}\right)$ was similar in all field trials. This pattern included two different phases whose duration varied according to each trial: phase I, starting at first detection of the pathogen, during which Popepi increased to reach maximum values of $8.5 \times$ $10^{6}, 1.5 \times 10^{6}$, and $3.2 \times 10^{4} \mathrm{CFU} / \mathrm{ml}$ in trials $\mathrm{A}, \mathrm{B}$, and $\mathrm{C}$, respectively; and phase II, during which Pop $_{\text {epi }}$ values decreased from maximum values (Fig. 2).

Number of weeks for first detection of $X$. albilineans (FD) after planting sugar-

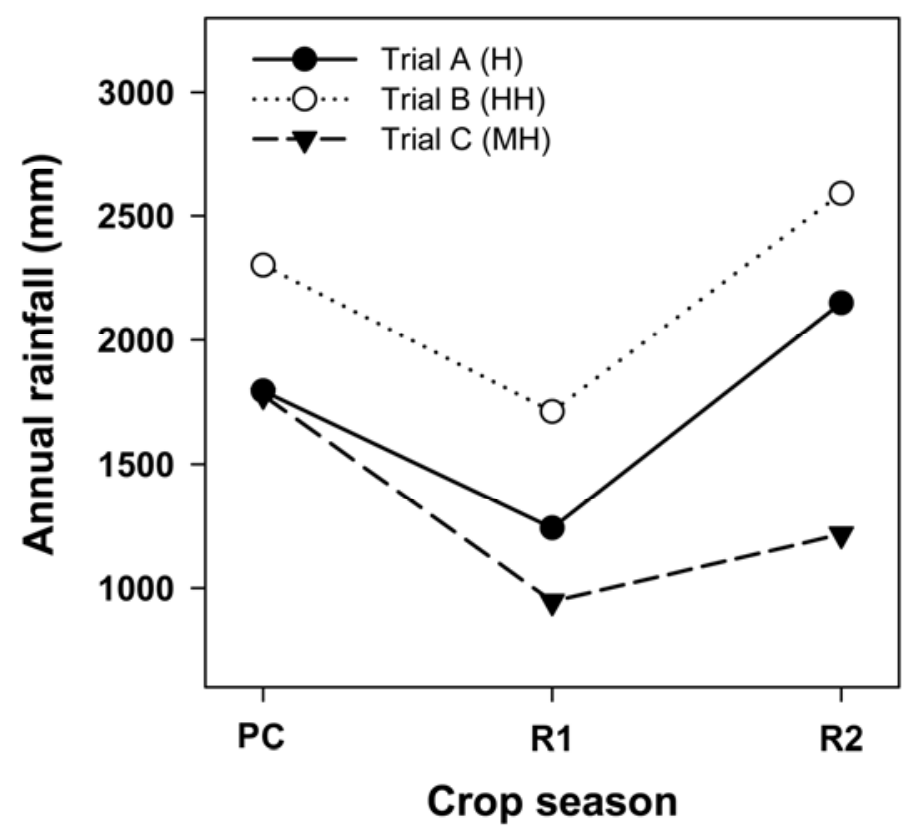

Fig. 1. Annual rainfall values based on cumulative daily rainfalls during three sugarcane crop seasons, plant cane crop (PC), 1st ratoon crop (R1), and 2nd ratoon crop (R2), in three field trials (A, B, and C) established under different environmental (agronomic and climatic) conditions in Guadeloupe. Abbreviations: $\mathrm{HH}=$ highly humid, $\mathrm{H}=$ humid, and $\mathrm{MH}=$ moderately humid. cane in fields, number of quadrates contaminated by the pathogen at the time of FD and at other dates of sampling after FD varied between trials (Table 3 ).

An aggregative dispersion of $X$. albilineans was detected 3 weeks after FD in trial A $(P=0.032)$, at FD and 3 weeks after FD in trial B $(P=0.0024$ and $P=$ 0.0011 , respectively), and 6 weeks after FD in trial $\mathrm{C}(P=0.003)$. A random dispersion of $X$. albilineans was found at FD, and 2 and 4 weeks after FD in trial C (Table 3).

Maximum epiphytic population density in first and second ratoon crops. In crop seasons R1 and R2, water droplets on the sugarcane leaf surface were sampled at the beginning (July), at the middle (September), and at the end (November) of the wet season in each trial (data not shown). Maximum values of epiphytic population densities were $4.1 \times 10^{4}$ and $4.6 \times 10^{5}$ $\mathrm{CFU} / \mathrm{ml}$ in trial A, $2.0 \times 10^{6}$ and $1.0 \times 10^{7}$ $\mathrm{CFU} / \mathrm{ml}$ in trial $\mathrm{B}$, and 2.2 and $6.4 \times 10^{1}$ $\mathrm{CFU} / \mathrm{ml}$ in trial $\mathrm{C}$, in crop seasons $\mathrm{R} 1$ and $\mathrm{R} 2$, respectively.

Severity and occurrence of symptoms in plant cane crop. Leaf symptoms attributed to aerial spread of $X$. albilineans were first observed 5 and 4 weeks after FD in trials $\mathrm{A}$ and $\mathrm{C}$, respectively (Fig. 2). The disease progress pattern was similar in both trials, and two phases were identified: phase I, when symptom severity increased rapidly to reach maximum values of 2.2 and 2.1 (on a scale of 0 to 5) in trials A and $\mathrm{C}$, respectively; and phase II, when symptom severity slowly decreased until the end of the PC crop to reach values of 1.0 and 1.7 in trials A and C, respectively (Fig. 2). At the end of PC crop, the percentage of stalks with leaf symptoms was $15.4 \%$ (35 of 226) and $17.9 \%$ (55 of 304) in trials A and $\mathrm{B}$, respectively.

Percentage of infected stalks. The percentage of infected stalks at base only, top only, base and top, and base or top of sugarcane stalks at the end of PC, R1, and R2 crops varied greatly among the three trials (Table 4). For each crop and each field trial, the number of stalks infected at stalk base only was always higher than the number of stalks infected at stalk top only (Table 4).

Relationships among rainfall, maximum epiphytic population density, and

Table 2. Rainfall data of each crop season in each of the three field trials (A, B, and C) established to study sugarcane stalk infection by Xanthomonas albilineans following aerial spread of this pathogen in Guadeloupe ${ }^{\mathrm{a}}$

\begin{tabular}{|c|c|c|c|c|c|c|c|c|c|}
\hline \multirow[b]{2}{*}{ Rainfall $^{\mathrm{b}}$} & \multicolumn{3}{|c|}{ Trial A (H) } & \multicolumn{3}{|c|}{ Trial B (HH) } & \multicolumn{3}{|c|}{ Trial C (MH) } \\
\hline & PC & R1 & $\mathbf{R 2}$ & PC & R1 & $\mathbf{R 2}$ & PC & $\mathbf{R 1}$ & $\mathbf{R 2}$ \\
\hline Mean & 150 & 104 & 179 & 192 & 143 & 216 & 148 & 79 & 101 \\
\hline Mean square & 91 & 58 & 109 & 76 & 78 & 120 & 77 & 51 & 57 \\
\hline Minimum & 46 & 31 & 33 & 97 & 34 & 37 & 39 & 25 & 4 \\
\hline Maximum & 637 & 209 & 379 & 443 & 338 & 520 & 600 & 184 & 180 \\
\hline
\end{tabular}

${ }^{a}$ Twelve-month crop seasons from the beginning of May to the end of April of the following year. Abbreviations: PC = plant crop, R1 = 1st ratoon crop, and $\mathrm{R} 2=2$ nd ratoon crop; $\mathrm{HH}=$ highly humid, $\mathrm{H}=$ humid, and $\mathrm{MH}=$ moderately humid.

b Monthly cumulated daily rainfall expressed in millimeters. 
percentage of infected stalks. Relationships among maximum epiphytic population density on leaves, percentage of infected stalks, and rainfall parameters, including number of rainy days, number of days with rainfall $>6 \mathrm{~mm}$, and total rainfall during the wet season (from the beginning of June to the end of December), were compared for each trial and each crop season. The highest linear correlation was found between maximum epiphytic population density and total rainfall data $(R=$ 0.88 ). However, a high correlation was also observed between percentage of in-

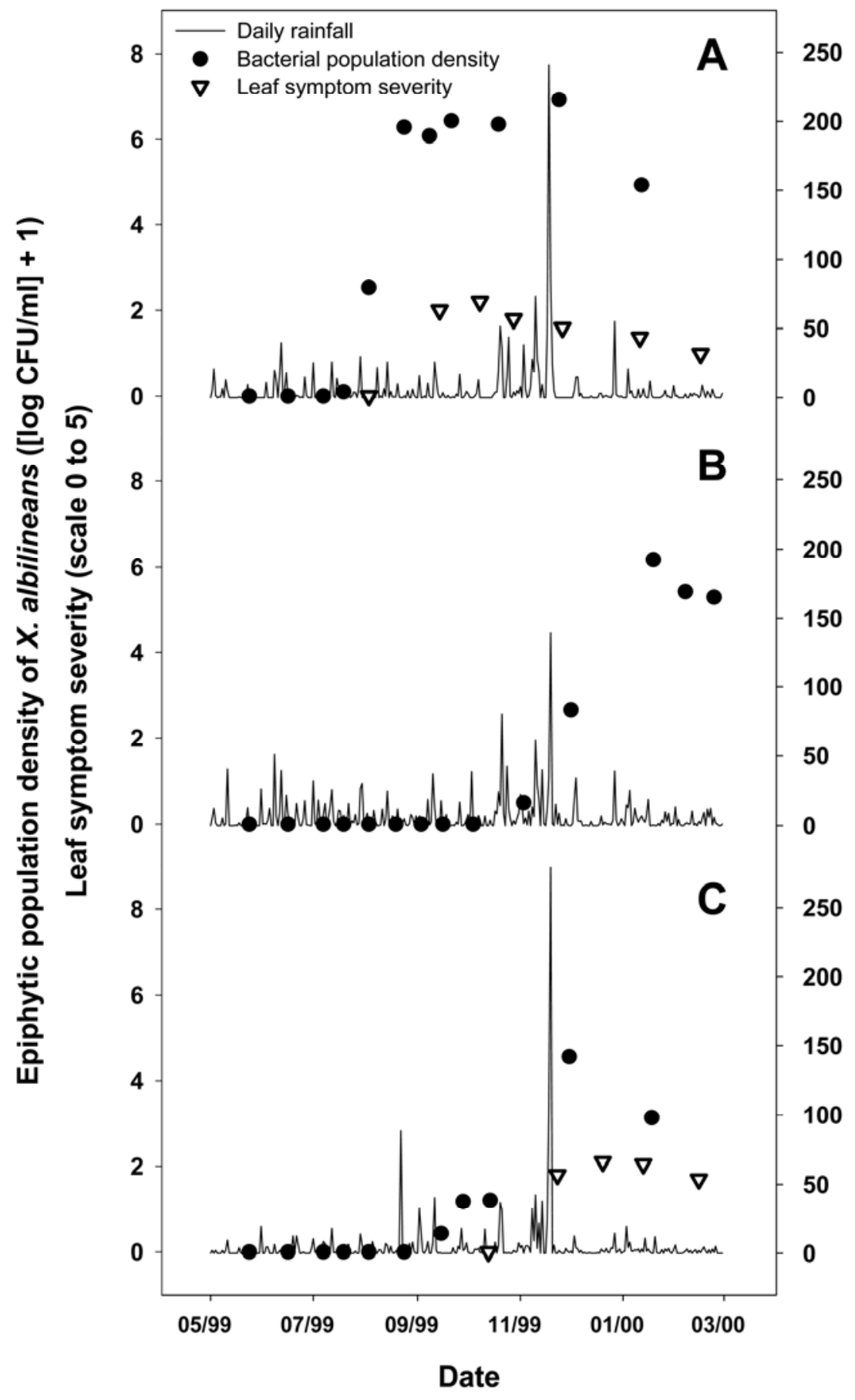

Fig. 2. Epiphytic population density of Xanthomonas albilineans and severity of leaf symptoms on sugarcane cv. B69566 in plant cane crop in three field trials (A, B, and C) established under different environmental conditions in Guadeloupe. Each of the three trials was divided into quadrates of 32 plants each, and populations of the pathogen were measured at different dates in water droplets (16 droplets per quadrate) sampled on leaf surface, and expressed as $\log ([\mathrm{CFU} / \mathrm{ml}]+1)$. Each value is the mean of epiphytic population densities of the pathogen measured in 25,35 , and 35 quadrates in trials A, B, and C, respectively. Disease symptoms were recorded on leaves at different dates after first detection of symptoms in trials A and C. Leaf symptom severity was assessed with a 0 to 5 scale. Each value is the mean of leaf symptom severity assessed with 20 plants that were arbitrarily selected among symptomatic plants in each of the two trials. Daily rainfall (mm) was monitored during the whole crop season in each of the three trials. fected stalks and total rainfall data $(R=$ 0.81; Table 5). Linear correlation between maximum epiphytic population density and percentage of infected stalks was also significant $(R=0.76)$. Nonlinear regressions were also tested and maximum epiphytic population density data were correlated with total rainfall data $(R=0.91)$ by the logarithmic nonlinear regression model $y=-47.36+7.33[\ln (x)]$ if $x>0$, where $x$ values corresponded to total rainfall data (Fig. 3). Percentage of infected stalk data were correlated to total rainfall data $(R=$ $0.98)$ by the sigmoid nonlinear regression model $y=1.96+32.19 /[1+\exp (-(x-$ $1,523) / 1.85)]^{0.019}$, where $x$ values corresponded to total rainfall data (Fig. 3). Maximum epiphytic population density was correlated to percentage of infected stalks $(R=0.94)$ by the exponential nonlinear regression model $y=1.17+$ $0.046 \mathrm{e}^{0.851 x}$, where $x$ values corresponded to maximum epiphytic population density data (Fig. 4).

\section{DISCUSSION}

In this study, we analyzed the relationships between epiphytic population density of $X$. albilineans after aerial contamination of sugarcane plants, leaf symptom severity, colonization of sugarcane stalks by the pathogen, and several endogenous or exogenous factors including strain variation of the pathogen and agronomic or climatic environmental conditions, with special emphasis on rainfall.

Aerial contamination of disease-free sugarcane plants by $X$. albilineans in three separate field trials established in 1999 under different environmental conditions confirmed previous results obtained with two sugarcane plots planted in 1998 in a humid, banana-growing location distant from other sugarcane fields in Guadeloupe (8). In this study, however, all tested strains of the pathogen belonged to serotype 1 (30), whereas serotype 1 and serotype 3 strains were found in the previous study (8).

The presence of sugarcane fields contaminated by $X$. albilineans in the proximity of the field trials appeared to be determinant in sugarcane phyllosphere contamination, as determined by first detection time of bacteria on sugarcane leaf surface in the plant cane crop. In trial A, which was set up in a humid location near other sugarcane fields, the pathogen was detected early in the crop season, 9 weeks after transferring healthy plants to the field, and without occurrence of any particular meteorological event. This suggested that short-distance spread of $X$. albilineans under normal rainy conditions can be responsible for nearby field-to-field plant contamination. Short-distance spread of other xanthomonads occurs either by dissemination of bacteria by water splashing $(17,24,28)$ or by passive transport by canopy fauna (15). In trial $C$, which was 
also established near other sugarcane fields but in a moderately humid area, occurrence of a tropical storm may have facilitated dispersion of the pathogen. In trial B, which was set up in a highly humid location distant to sugarcane fields, late detection of bacteria ( 25 weeks after transferring plants to the field), and only after passage of tropical storm Jose, suggested that sugarcane field contamination can result from long-distance spread of $X$. albilineans favored by particular meteorological events. Similarly, tropical storms were associated with long-distance spread of Xanthomonas citri pv. citri in La Reunion Island (28) and in Florida (16).

After first detection, the $X$. albilineans population extended rapidly on the leaf canopy in the highly humid area (trial B). Small-scale plot size and rapidity of entire canopy contamination did not allow us to clearly identify a major bacterial dispersion type in the sugarcane field. However, a transient aggregative phase occurred in the plots in the humid and highly humid areas (trials A and B, respectively), suggesting local dispersion of the bacteria and main movement of the pathogen through splashing or local transport. During epidemic expansion in the humid area and highly humid areas, bacteria population densities reached 1 to 10 million bacteria per milliliter of water available on leaves. However, these population densities decreased when cane approached maturity and rain decreased. On the other hand, in the moderately humid area (trial C), X. albilineans population dispersion on sugarcane leaves was heterogeneous and not aggregative before arrival of tropical depressions and heavy rainfalls. When climatic conditions are not favorable, $X$. albilineans may be present sporadically on leaf surfaces, as rain was shown to favor bacterial growth on infected plants (27) and subsequent dispersal of bacteria on the leaf canopy (3).

Interestingly, at the end of the rainy season in the plant cane crop, maximum epiphytic bacterial populations were higher in trials A and B, set up in humid and highly humid areas, respectively, than in trial $\mathrm{C}$, set up in a moderately humid area, and this even when first detection of bacteria in trial $\mathrm{C}$ occurred 8 weeks sooner than in trial B. These results first suggested a relationship between rainfall and maximum populations of $X$. albilineans on the leaf surface. This relationship will be confirmed by comparison of data obtained in the three crop cycles of the three trials, as discussed below.

Necrotic symptoms resulting from leaf infection after aerial transmission of $X$. albilineans appeared 3 to 5 weeks after first detection of the bacterium in leaf surface water, confirming the important role of epiphytic life of $X$. albilineans in plant contamination. A previous report mentioned a period of 7 weeks between first detection of a virulent $X$. albilineans strain on leaves and symptom appearance (8). This time difference may be related to either local environmental conditions or strain variation of the pathogen. No variation was found in this study among 54 strains isolated in the three field trials, based on variability of a $55-\mathrm{kb}$ genomic region involved in biosynthesis of the toxin albicidin, but differences in ability to induce symptoms and to colonize the stalk existed among these strains (4). Strain pathogenicity was not required for epiphytic growth of Pseudomonas syringae under high relative humidity, but was required to access and multiply in protected sites of the phyllosphere prior to plant infection (40). Therefore, it cannot be excluded that variation in pathogenicity of $X$. albilineans contributes to its ability to induce leaf symptoms on sugarcane. Further studies are needed to investigate the role of strain variation in capacity to colo-

Table 3. Spatial data analysis of Xanthomonas albilineans dispersion in plant cane crop in three field trials (A, B, and C) established to study sugarcane stalk infection by X. albilineans following aerial spread of this pathogen in Guadeloupe ${ }^{\mathrm{a}}$

\begin{tabular}{|c|c|c|c|c|}
\hline \multirow[b]{2}{*}{ Trial } & \multirow{2}{*}{$\begin{array}{c}\text { Date of } \\
\text { sampling }\end{array}$} & \multirow{2}{*}{$\begin{array}{c}\text { Quadrate } \\
\text { contamination }{ }^{\mathrm{d}} \mathrm{Q}_{\mathrm{p}} / \mathrm{T}\end{array}$} & \multicolumn{2}{|c|}{ Moran's test ${ }^{b}$} \\
\hline & & & $\mathbf{M}_{\mathbf{i}}$ & $P$ \\
\hline \multirow[t]{3}{*}{$\overline{\mathrm{A}(\mathrm{H})}$} & FD & $1 / 14$ & & \\
\hline & $+3 w k$ & $12 / 27$ & 1.84 & 0.032 \\
\hline & $+6 \mathrm{wk}$ & $27 / 27$ & & \\
\hline \multirow[t]{3}{*}{ B (HH) } & FD & $6 / 18$ & 2.84 & 0.0024 \\
\hline & $+3 \mathrm{wk}$ & $23 / 35$ & 3.85 & 0.0011 \\
\hline & $+6 \mathrm{wk}$ & $35 / 35$ & $\ldots$ & \\
\hline \multirow[t]{5}{*}{$\mathrm{C}(\mathrm{MH})$} & FD & $4 / 17$ & -0.67 & 0.74 \\
\hline & $+2 \mathrm{wk}$ & $11 / 35$ & 0.38 & 0.35 \\
\hline & $+4 \mathrm{wk}$ & $7 / 35$ & 0.37 & 0.35 \\
\hline & $+6 w k$ & $33 / 35$ & 2.77 & 0.003 \\
\hline & $+9 \mathrm{wk}$ & $33 / 35$ & 2.77 & 0.003 \\
\hline
\end{tabular}

a Dispersion of $X$. albilineans through the field is based on relative geographical distribution of positive vs. negative quadrates. Analyses were performed with data of the contamination process, i.e., from first detection of $X$. albilineans until all quadrates of the studied field were contaminated by the pathogen (trials $\mathrm{A}$ and $\mathrm{B}$ ) or until the end of the crop season (trial C). Abbreviations: $\mathrm{HH}=$ highly humid, $\mathrm{H}=$ humid, and $\mathrm{MH}=$ moderately humid.

${ }^{\mathrm{b}}$ Based on contaminated quadrate analyses. $\mathrm{M}_{\mathrm{i}}=$ Moran's index.

${ }^{\mathrm{c}}$ First detection of $X$. albilineans (FD) and weeks (wk) after FD in the field. FD occurred 9, 25, and 17 weeks after transferring sugarcane plants to the field in trials A, B, and C, respectively. Water droplets were sampled in all quadrates and on every two plants ( 16 droplets sampled per quadrate).

${ }^{\mathrm{d}} \mathrm{Q}_{\mathrm{p}}=$ contaminated quadrate and $\mathrm{T}=$ total number of quadrates.

Table 4. Number of infected stalks at the end of each crop season (PC, R1, and R2) in the three field trials (A, B, and C) established to study sugarcane stalk infection by Xanthomonas albilineans following aerial spread of this pathogen in Guadeloupe ${ }^{\mathrm{a}}$

\begin{tabular}{lccccc}
\hline \multirow{2}{*}{$\begin{array}{l}\text { Trial-crop } \\
\text { season }\end{array}$} & \multirow{2}{*}{$\begin{array}{l}\text { Total no. } \\
\text { of stalks }\end{array}$} & \multicolumn{4}{c}{ Number of infected stalks (\%) at } \\
\cline { 3 - 6 } & 226 & $33(14.6)$ & $2(0.9)$ & $6(2.6)$ & $41(18.1)$ \\
\hline A (H)-PC & 226 & $7(3.1)$ & $0(0)$ & $1(0.4)$ & $8(3.5)$ \\
A (H)-R1 & 262 & $27(10.3)$ & $2(0.7)$ & $15(5.7)$ & $44(16.8)$ \\
A (H)-R2 & 304 & $9(3.0)$ & $7(2.3)$ & $1(0.3)$ & $17(5.6)$ \\
B (HH)-PC & 304 & $13(4.3)$ & $2(0.6)$ & $8(2.6)$ & $23(7.6)$ \\
B (HH)-R1 & $\ldots$ & $\ldots$ & $\ldots$ & $\ldots$ & $\ldots$ \\
B (HH)-R2 & 216 & $5(2.3)$ & $1(0.5)$ & $0(0)$ & $6(2.8)$ \\
C (MH)-PC & 216 & $3(1.4)$ & $2(0.9)$ & $0(0)$ & $5(2.3)$ \\
C (MH)-R1 & 200 & $1(0.01)$ & $0(0)$ & $0(0)$ & $1(0.5)$ \\
C (MH)-R2 & & &
\end{tabular}

${ }^{a}$ Twelve-month crop seasons from the beginning of May to the end of April of the following year Abbreviations: $\mathrm{HH}=$ highly humid, $\mathrm{H}=$ humid, and $\mathrm{MH}=$ moderately humid; $\mathrm{PC}=$ plant cane crop, $\mathrm{R} 1=1$ st ratoon crop, and $\mathrm{R} 2=2 \mathrm{nd}$ ratoon crop.

${ }^{\mathrm{b}}$ Stalk infection at the end of the R2 crop season was not assessed because of late harvesting of sugarcane at the end of the R1 crop; and R2 crop of trial B was not therefore synchronous with the same crop of the two other trials. 
age of stalks with leaf symptoms, since the percentages of stalks with leaf symptoms were very similar in trials A and B (15 and $18 \%$, respectively), whereas the percentages of infected stalks clearly differed between the two trials (18.1 and 5.6\% in trials $\mathrm{A}$ and $\mathrm{B}$, respectively). These data revealed that the pathogen did not penetrate the stalk from all diseased leaves or that stalk colonization can occur even in the absence of visible leaf symptoms. Therefore, leaf symptom assessment cannot be used to reliably predict stalk colonization after aerial contamination by $X$. albilineans. When considering only colonization of stalks with leaf symptoms, main infections (assessed by presence of bacteria at the base and the top of the stalk) occurred in stalks that showed the most severe leaf symptoms, indicating that bacteria penetrated the stalk from most diseased leaves. Additionally, the sooner $X$. albilineans arrived on the leaf canopy, the higher was the percentage of colonized base parts of the sugarcane stalks: 53\% (9 of 17) of infected stalks were colonized only in the base part in trial $\mathrm{B}$, whereas $80 \%$ (33 of 41 ) and $83 \%$ (5 of 6) were colonized only in the base part in the two other trials whose canopy was contaminated by the pathogen 16 weeks (trial A) and 8 weeks (trial C) earlier. These results suggested that susceptibility to systemic colonization by epiphytic populations of $X$. albilineans is more important in young plants than in older ones. Stomata number and activity varies according to the physiological stage of plants and appears to be more important in young and fast-growing plants (19). As a consequence, young fastgrowing plants may be more susceptible to bacterial invasion through stomata, al- though stomata-based defense against plant pathogens may exist (38). Furthermore, $X$. albilineans is more likely to colonize the sugarcane stalk if aerial contamination of the foliage occurs early during the growth cycle.

Primary contamination of a disease-free sugarcane plot was previously reported in plant cane crop (8), but this is the first report of sugarcane contamination in successive ratoon crops. Maximum epiphytic populations of the pathogen and percentage of infected stalks varied in the successive crops and, surprisingly, the percentage of infected stalks did not always increase from one crop cycle to the next. Because $X$. albilineans can be spread from systematically infected plants during harvest using cutting knives $(13,29)$, infection of healthy stalks should have occurred during harvest and should have resulted in an increase in the percentage of infected stalks from one crop season to the next. In Guadeloupe, recovery of sugarcane plants, i.e., decrease in percentage of infected stalks from one crop cycle to the next, has already been observed under field (J.-H. Daugrois, personal communication) and experimental conditions (31). Therefore, it can be hypothesized that, under specific environmental conditions, the transmission of $X$. albilineans from infected plants to healthy ones during manual harvest is of minor importance in the epidemiology of this pathogen. Additionally, bacteria may not have colonized the base of the stool (which corresponds to the underground stubble from which ratoon crops emerge) before harvest, and were therefore absent in the newly growing plant that developed from the stalk tissue remaining in the soil. More likely, infected stools or young stems emerging from infected stools may fail to produce mature stalks because of competition with noninfected plants. However, these infected stools may have served as an inoculum source for the pathogen at an early stage of growth. Additionally, synchronous detection of bacteria in leaves of the three trials in ratoon crops R1 and R2 (data not shown) suggests that primary inoculum in these ratoon crops originated from infected plants within fields.

High correlation $(R=0.88)$ between total rainfall and maximum population densities of the pathogen on leaf surface in the three trials and in three crop cycles confirmed the relationship that was suggested in plant cane crop. Additionally, a high correlation $(R=0.81)$ existed between total rainfall and percentage of infected stalks, and this correlation corroborated the correlation established herein between bacterial population density on leaves and percentage of infected stalks $(R=0.76)$. For each of these correlations, a nonlinear regression model was used to describe the distribution of the data with highly significant $R$ values $(R>0.91)$. This is first evidence of a relationship between rainfall and epiphytic bacterial populations and subsequent plant infection of a perennial crop. The high correlation between total rainfall and percentage of infected stalks is further evidence that transmission of $X$. albilineans at harvest plays a minor role in the epidemiology of the pathogen in Guadeloupe.

Rain events have already been shown to affect bacterial dynamics on leaves (37), and cumulative rainfall may also have an effect on epiphytic bacterial populations and subsequent plant contamination. $\mathrm{Cu}-$ mulative rainfall during the growing sea-

Table 5. Rainfall data, maximum epiphytic population density, and percent infected stalks during each crop season (PC, R1, and R2) of the three field trials (A, B, and C) established to study sugarcane stalk infection by Xanthomonas albilineans following aerial spread of this pathogen in Guadeloupe ${ }^{\mathrm{a}}$

\begin{tabular}{|c|c|c|c|c|c|}
\hline \multirow[b]{2}{*}{ Trial-crop season } & \multicolumn{3}{|c|}{ Rainfall data $^{b}$} & \multirow[b]{2}{*}{$\begin{array}{c}\text { Maximum population } \\
\text { density }^{c}\end{array}$} & \multirow[b]{2}{*}{$\begin{array}{l}\text { Percent infected } \\
\text { stalks }^{\mathrm{d}}\end{array}$} \\
\hline & Total rainfall & $\begin{array}{l}\text { No. of } \\
\text { rainy days }\end{array}$ & $\begin{array}{l}\text { No. of significant } \\
\text { rainy days }\end{array}$ & & \\
\hline $\mathrm{A}(\mathrm{H})-\mathrm{PC}$ & 1,451 & 116 & 44 & 6.93 & 18.1 \\
\hline$A(H)-R 1$ & 950 & 120 & 44 & 4.61 & 3.5 \\
\hline A (H)-R2 & 1,438 & 152 & 48 & 5.67 & 16.8 \\
\hline B (HH)-PC & 1,615 & 156 & 67 & 6.18 & $5.6^{\mathrm{e}}$ \\
\hline B (HH)-R1 & 1,325 & 146 & 62 & 6.30 & 7.6 \\
\hline B (HH)-R2 & 1,839 & 156 & 80 & 7.02 & $\ldots$ \\
\hline $\mathrm{C}(\mathrm{MH})-\mathrm{PC}$ & 1,264 & 133 & 34 & 4.51 & 2.8 \\
\hline $\mathrm{C}(\mathrm{MH})-\mathrm{R} 1$ & 751 & 126 & 31 & 0.34 & 2.3 \\
\hline $\mathrm{C}(\mathrm{MH})-\mathrm{R} 2$ & 917 & 134 & 42 & 1.81 & 0.5 \\
\hline \multicolumn{6}{|c|}{ Correlation analysis ( $R$ value) } \\
\hline Population density & 0.88 & 0.43 & 0.68 & $\ldots$ & 0.76 \\
\hline Infected stalks & 0.81 & 0.04 & 0.38 & 0.76 & $\ldots$ \\
\hline
\end{tabular}

a Twelve-month crop seasons from the beginning of May to the end of April of the following year. Abbreviations: $\mathrm{HH}=$ highly humid, $\mathrm{H}=$ humid, and $\mathrm{MH}$ $=$ moderately humid; $\mathrm{PC}=$ plant cane crop, $\mathrm{R} 1=1$ st ratoon crop, and $\mathrm{R} 2=2$ nd ratoon crop.

b Data were obtained during the wet season (from the beginning of June to the end of December). Total rainfall corresponds to cumulated daily rainfall expressed in millimeters. Number of significant rainy days corresponds to the number of days with rainfall $>6 \mathrm{~mm}$.

c Maximum mean value of epiphytic population densities of the pathogen determined at different sampling dates in 25, 35, and 35 quadrates in trials A, B, and $\mathrm{C}$, respectively. Each of the three trials was divided into quadrates of 32 plants each, and populations of the pathogen were measured in water droplets (16 droplets sampled by quadrate) sampled at leaf surface of sugarcane cv. B69566 and expressed as $\log ([\mathrm{CFU} / \mathrm{ml}]+1)$.

${ }^{\mathrm{d}}$ Stalks infected by $X$. albilineans at the base or top of the sugarcane stalk, at the end of the crop season.

e This value was not included in the calculation of correlations because initial infection of sugarcane in trial B was delayed compared to trials A and C (due to absence of sugarcane fields in the proximity of trial B), resulting in a different infection pattern in plant cane (PC). 

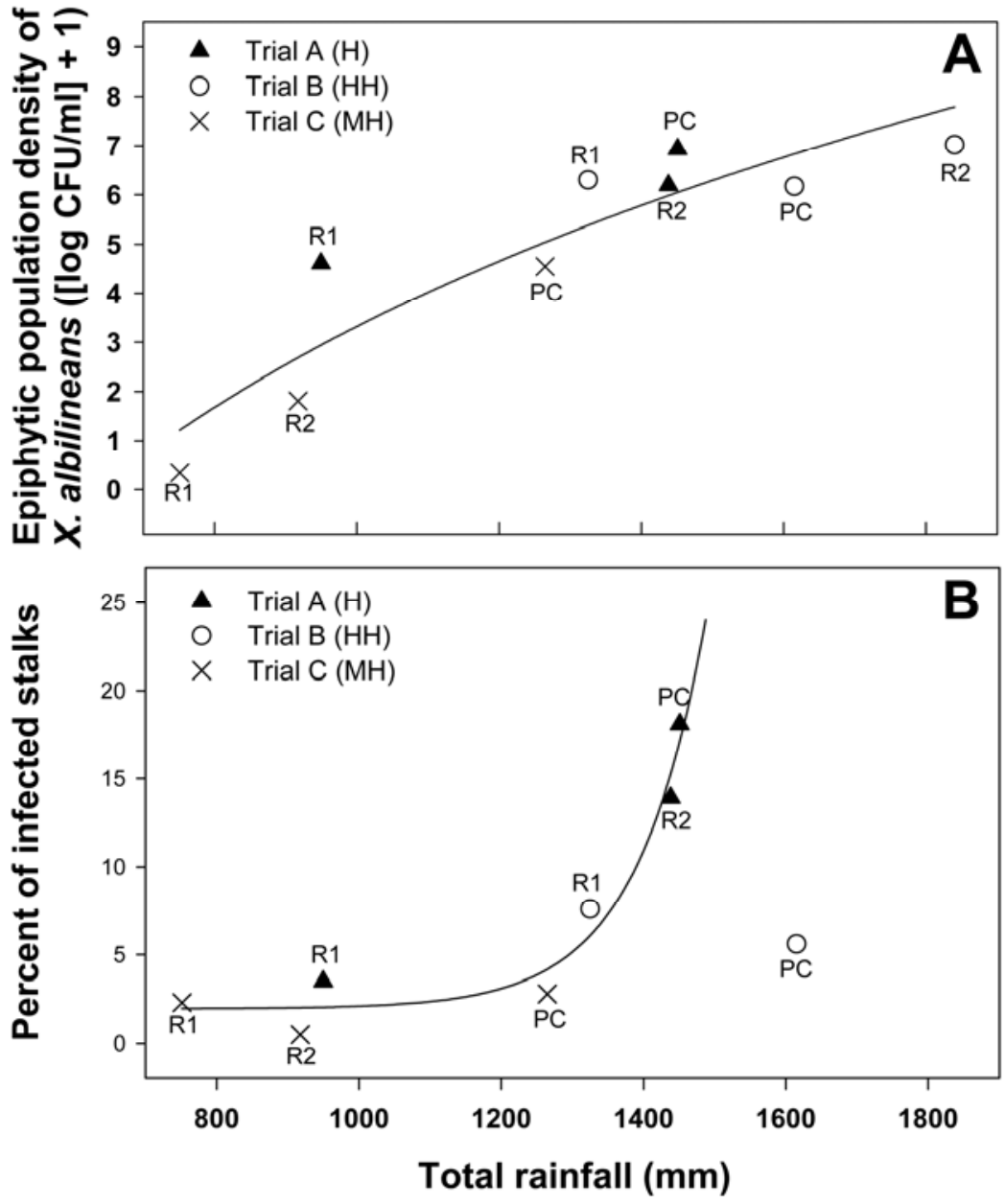

Fig. 3. Distribution of A, maximum values of epiphytic population density of Xanthomonas albilineans and $\mathbf{B}$, percent stalks infected by the pathogen in relation to total rainfall during the wet season (from the beginning of June to the end of September) during three crop seasons (CP, R1, and R2) and in three field trials (A, B, and C). The logarithmic curve (A) and the sigmoid curve (B) correspond to the models that best fit distribution of the data and were obtained by nonlinear regression analyses. Abbreviations: $\mathrm{HH}=$ highly humid, $\mathrm{H}=$ humid, and $\mathrm{MH}=$ moderately humid.

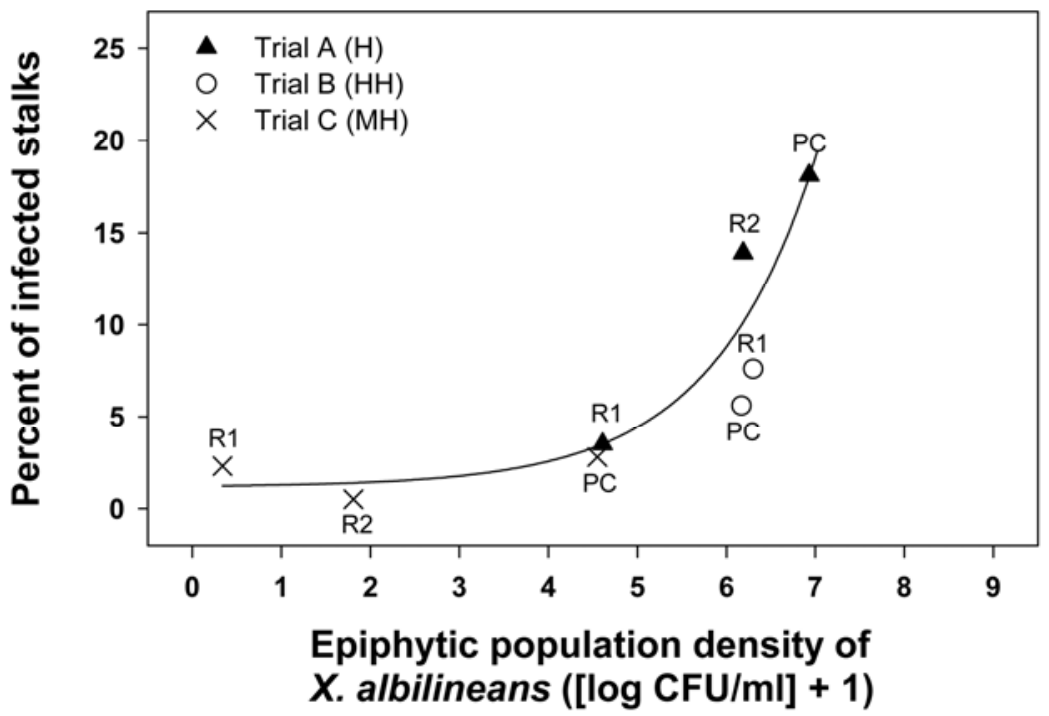

Fig. 4. Distribution of percent stalks infected by Xanthomonas albilineans in relation to maximum epiphytic population density of the pathogen during three crop seasons (CP, R1, and R2) and in three field trials ( $\mathrm{A}, \mathrm{B}$, and $\mathrm{C}$ ). The exponential curve corresponds to the model that best fit distribution of the data and was obtained by nonlinear regression analysis. Abbreviations: $\mathrm{HH}=$ highly humid, $\mathrm{H}=$ humid, and $\mathrm{MH}=$ moderately humid. son of garlic was related to the number of plants infected by Xanthomonas axonopodis pv. alii (32). Similarly, a strong relationship was established between cumulative rainfall and symptom severity of leaf blight of onion caused by Xanthomonas campestris (34). Dynamics of epiphytic bacterial populations are associated with exchanges between inner and outer leaf spaces $(35,38)$. These exchanges are strongly linked to continuum between the two spaces and associated to leaf lesions and stomata. Thus, stomata opening, which was shown to be promoted by water reserve in soil (38), may also be linked to rainfall. Therefore, we hypothesize that stalk colonization of sugarcane following aerial spread of $X$. albilineans is favored by humidity on leaves and stomata opening due to rainfall. This study was conducted with sugarcane cv. B69566, which is susceptible to leaf scald (31). Additional data should be obtained with other sugarcane cultivars differing in susceptibility to the disease in order to confirm the correlation described above. Additionally, little is known about the importance of the epiphytic phase of $X$. albilineans on progress of leaf scald disease in different sugarcane cultivars. This needs to be investigated because resistance of sugarcane to leaf scald has so far only been determined after artificial inoculation of plants $(23,31)$. Rainfall appears to be a key factor in leaf colonization of sugarcane and subsequent plant infection by $X$. albilineans after aerial spread of the pathogen. This observation may result in modifications of disease resistance screening and propagation of healthy plant material, especially in humid tropical areas.

\section{ACKNOWLEDGMENTS}

We thank the tissue culture laboratory of Cirad in Guadeloupe for the supplying of sugarcane tissue cultured plants, R. Boisne-Noc and S. Joseph for field and laboratory support, and R. E. Stall for critical reviewing of the manuscript.

\section{LITERATURE CITED}

1. Autrey, L. J. C., Saumtally, S., Dookun, A., Sullivan, S., and Dhayan, S. 1995. Aerial transmission of the leaf scald pathogen, Xanthomonas albilineans. Proc. Int. Soc. Sugar Cane Technol. 21:508-526.

2. Birch, R. G. 2001. Xanthomonas albilineans and the antipathogenesis approach to disease control. Mol. Plant Pathol. 2:1-11.

3. Bock, C. H., Parker, P. E., and Gottwald, T. R. 2005. Effect of simulated wind-driven rain on duration and distance of dispersal of Xanthomonas axonopodis pv. citri from cankerinfected citrus trees. Plant Dis. 89:71-80.

4. Champoiseau, P., Daugrois, J.-H., Girard, J.C., Royer, M., and Rott, P. C. 2006. Variation in albicidin biosynthesis genes and in pathogenicity of Xanthomonas albilineans, the sugarcane leaf scald pathogen. Phytopathology 96:33-45.

5. Chen, C. T., Lin, C. P., and Liang, Y. G. 1993. Leaf scald of sugarcane in Taiwan. Taiwan Sugar 40:8-16.

6. Comstock, J. C. 2001. Foliar symptoms of sugarcane leaf scald. Sugar J. 64:23-32.

7. Comstock, J. C., and Shine, J. M., Jr. 1992. 
Outbreak of leaf scald of sugarcane, caused by Xanthomonas albilineans, in Florida. Plant Dis. 76:426.

8. Daugrois, J.-H., Dumont, V., Champoiseau, P., Costet, L., Boisne-Noc, R., and Rott, P. 2003. Aerial contamination of sugarcane in Guadeloupe by two strains of Xanthomonas albilineans. Eur. J. Plant Pathol. 109:445-458.

9. Davis, M. J., Rott, P., Baudin, P., and Dean, J. L. 1994. Evaluation of selective media and immunoassays for detection of Xanthomonas albilineans, causal agent of sugarcane leaf scald disease. Plant Dis. 78:78-82.

10. Davis, M. J., Rott, P., Warmuth, C. J., Chatenet, M., and Baudin, P. 1997. Intraspecific genomic variation within Xanthomonas albilineans, the sugarcane leaf scald pathogen. Phytopathology 87:316-324.

11. Diaz, M., Peralta, E. L., Iglesia, A., Pazos, V., Carvajal, O., Perez, M. P., Giglioti, E. A., Gagliardi, P. R., Wendland, A., and Camargo, L. E. A. 2001. Xanthomonas albilineans haplotype B responsible for a recent sugarcane leaf scald disease outbreak in Cuba. Plant Dis. 85:334.

12. Egan, B. T., and Sturgess, O. W. 1980. Commercial control of leaf scald disease by thermotherapy and a clean seed program. Proc. Int. Soc. Sugar Cane Technol. 17:1602-1606.

13. Fauconnier, R. 1991. La canne à sucre. Le technicien d'agriculture tropicale. Maisonneuve et Larose, Paris, France.

14. Feldmann, P., Sapotille, J., Grédoire, P., and Rott, P. 1994. Micropropagation of sugarcane. Pages 15-17 in: In Vitro Culture of Tropical Plants. C. Teisson, ed. La Librairie du Cirad, Montpellier, France.

15. Gottwald, T. R., Bassanezi, R. B., Amorim, L., and Bergamin-Filho, A. 2007. Spatial pattern analysis of citrus canker-infected plantings in Sao Paulo, Brazil, and augmentation of infection elicited by the Asian leafminer. Phytopathology 97:674-683.

16. Gottwald, T. R., Sun, X., Riley, T., Graham, J. H., Ferrandino, F., and Taylor, E. L. 2002. Geo-referenced spatiotemporal analysis of the urban citrus canker epidemic in Florida. Phytopathology 92:361-377.

17. Gottwald, T. R., Timmer, L. W., and McGuire, R. G. 1989. Analysis of disease progress of cit- rus canker in nurseries in Argentina. Phytopathology 79:1276-1283.

18. Grisham, M. P., Legendre, B. L., and Comstock, J. C. 1993. First report of leaf scald, caused by Xanthomonas albilineans, of sugarcane in Louisiana. Plant Dis. 77:537.

19. Hetherington, A. M., and Woodward, F. I. 2003. The role of stomata in sensing and driving environmental change. Nature 424:901907.

20. Hoy, J. W., and Grisham, M. P. 1994. Sugarcane leaf scald distribution, symptomatology, and effect on yield in Louisiana. Plant Dis. 78:1086-1087.

21. Isakeit, T., and Irvine, J. E. 1995. First report of leaf scald, caused by Xanthomonas albilineans, of sugarcane in Texas. Plant Dis. 79:860.

22. Klett, P., and Rott, P. 1994. Inoculum sources for the spread of leaf scald disease of sugarcane caused by Xanthomonas albilineans in Guadeloupe. J. Phytopathol. 142:283-291.

23. Koike, H. 1965. The aluminum cap method for testing sugarcane varieties against leaf scald disease. Phytopathology 55:317-319.

24. Milus, E. A., and Mirlohi, A. F. 1993. A test tube assay for estimating populations of Xanthomonas campestris pv. translucens on individual wheat leaves. Phytopathology 83:134139.

25. Moran, P. A. P. 1950. A test for serial independence of residuals. Biometrika 37:178-181.

26. Ovalle, W., Comstock, J., Juarez, J., and Soto, G. 1995. First report of leaf scald of sugarcane (Xanthomonas albilineans) in Guatemala Plant Dis. 79:212.

27. Pietrarelli, L., Balestra, G. M., and Varvaro, L. 2006. Effects of simulated rain on Pseudomonas syringae pv. tomato populations on tomato plants. J. Plant Pathol. 88:245-251.

28. Pruvost, O., Gottwald, T. R., and Brocherieux, C. 1999. The effect of irrigation practices on the spatio-temporal increase of Asiatic citrus canker in simulated nursery plots in Réunion Island. Eur. J. Plant Pathol. 105:23-37.

29. Rott, P., and Davis, M. J. 2000. Leaf scald. Pages 38-44 in: A Guide to Sugarcane Diseases. P. Rott, R. A. Bailey, J. C. Comstock, B. J. Croft, and A. S. Saumtally, eds. La Librairie du Cirad, Montpellier, France.

30. Rott, P., Davis, M. J., and Baudin, P. 1994.
Serological variability in Xanthomonas albilineans, causal agent of leaf scald disease of sugarcane. Plant Pathol. 43:344-349.

31. Rott, P., Mohamed, I. S., Klett, P., Soupa, D., de Saint-Albin, A., Feldmann, P., and Letourmy, P. 1997. Resistance to leaf scald disease is associated with limited colonization of sugarcane and wild relatives by Xanthomona albilineans. Phytopathology 87:1202-1213.

32. Roumagnac, P., Pruvost, O., Chiroleu, F., and Hughes, G. 2004. Spatial and temporal analyses of bacterial blight of onion caused by Xanthomonas axonopodis pv. allii. Phytopathology 94:138-146.

33. Saumtally, S., Medan, H., and Autrey, L. J. C. 1996. Evolution of aerial infection of leaf scald caused by Xanthomonas albilineans (Ashby) Dowson in sugarcane. Proc. Int. Soc. Sugar Cane Technol. 22:493-496.

34. Schwartz, H. F., Otto, K. L., and Gent, D. H. 2003. Relation of temperature and rainfall to development of Xanthomonas and Pantoea leaf blights of onion in Colorado. Plant Dis. 87:1114

35. Smit, M. A., and Singels, A. 2005. The response of sugarcane canopy development to water stress. Field Crops Res. 98:91-97.

36. Stromberg, K. D., Kinkel, L. L., and Leonard, K. J. 1999. Relationship between phyllosphere population sizes of Xanthomonas translucen pv. translucens and bacterial leaf streak severity on wheat seedlings. Phytopathology $89: 131-135$

37. Tichich, R. P., Doll, J. D., and McManus, P. S 2006. Pseudomonas syringae pv. tagetis (PST) population dynamics both on and in Canada thistle (Cirsium arvense) leaves as affected by rain events. Weed Sci. 54:934-940.

38. Underwood, W., Melotto, M., and He, S. Y. 2007. Role of plant stomata in bacterial invasion. Cell. Microbiol. 9:1621-1629.

39. Walker, D. I. T. 1971. Breeding for resistance. Pages 445-502 in: Sugarcane Improvement Through Breeding. J. D. Heinz, ed. Elsevie Science Publishers, B.V., Amsterdam.

40. Wilson, M., Hirano, S. S., and Lindow, S. E. 1999. Location and survival of leaf-associated bacteria in relation to pathogenicity and potential for growth within the leaf. Appl. Environ. Microbiol. 65:1435-1443. 